\title{
PEMBIAYAAN DEFISIT DENGAN UTANG DAN KETAHANAN FISKAL DI INDONESIA
}

\author{
La Ode Suriadi \\ Fakultas Ekonomi, Universitas Haluoleo \\ Jln. H.E.A Mokodompit No. 1, Malaka Anduonohu, Kota Kendari 93232 \\ idsuriadi@gmail.com
}

\begin{abstract}
The focus of this study is to analyze the fiscal sustainability in Indonesia. To achieve these objectives, multiple regression model was constructed by the method of ordinary least squares (OLS). This model modified of the model of Buiter, Cudington, and Din. H.T. Data were collected from various sources such as the World Bank, Asian Development Bank, Bank of Indonesia, the Ministry of Finance of the Republic of Indonesia and the Indonesian Central Bureau of Statistics. The data are in the form of time series from 1980 - 2011. The results indicated that the budget deficit financing via debt (both foreign debt and domestic debt) still maintaining fiscal sustainability. This indication is seen from the change in value of the primary surplus that causes the debt ratio has decreased. Besides debt financing (both foreign debt and domestic debt) does not significantly causes the debt ratio increases.
\end{abstract}

Keywords: deficit, external debt, internal debt, fiscal sustainable

\begin{abstract}
ABSTRAK
Fokus penelitian ini adalah untuk menganalisis kesinambungan fiskal di Indonesia. Untuk mencapai tujuan tersebut, model regresi yang dibangun adalah ordinary least squares (OLS). Metode ini merupakan modifikasi dari model Buiter, Cudington dan Din. H.T. Data diambil dari World Bank, Asian Development Bank, Bank Indonesia, Kementerian Keuangan Indonesia, dan Badan Pusat Statistik. Data tersebut adalah time series tahun 1980-2011. Hasil menunjukkan bahwa pembiayaan defisit anggaran pemerintah (baik pinjaman luar maupun dalam negeri) masih mempertahankan ketahanan fiskal. Ini adalah indikasi adanya perubahan nilai surplus primer yang menyebabkan rasio utang pemerintah telah berkurang. Selain itu, dana utang (baik dari luar maupun dalam negeri) tidak dapat menyebabkan kenaikan rasio utang
\end{abstract}

Kata kunci: defisit, external debt, internal debt, ketahanan fiskal 


\section{PENDAHULUAN}

Kebijakan fiskal yang berkelanjutan merupakan topik yang sangat penarik untuk dikaji dalam perekonomian Indonesia. Kebijakan fiskal merupakan upaya-upaya pemerintah dalam membuat rencana-rencana ekonomi yang bertujuan untuk menyejahterakan rakyat. Sering kali kebijakan yang dibuat tersebut memberi efek positif terhadap pertumbuhan ekonomi dan kesejahteraan rakyat, namun sering pula kebijakan itu memberi efek negatif terhadap aktivitas yang lain.

Sebagai contoh, keberhasilan pemerintah dalam memulihkan perekonomian melalui ekspansi fiskal yang dijalankan selama ini. Ekspansi fiskal yang dijalankan pemerintah telah berhasil mengeluarkan Indonesia dari krisis, mulai dari krisis ekonomi tahun 1997-1998 maupun krisis global yang terjadi tahun 2009 yang lalu. Namun berbagai ekspansi fiskal yang dijalankan pemerintah tersebut membawa konsekuensi lain yakni meningkatnya pembiayaan fiskal terutama yang bersumber dari utang. Bahkan sejak tahun 1990-an utang telah menjadi sumber utama pembiayaan fiskal. Gambaran ini dapat dilihat pada tabel berikut:

Tabel 1 Sumber Pembiayaan Defisit APBN 2006-2011 (Triliun Rupiah)

\begin{tabular}{lccccccccr}
\hline & $\mathbf{1 9 8 0}$ & $\mathbf{1 9 9 0}$ & $\mathbf{2 0 0 0}$ & $\mathbf{2 0 0 6}$ & $\mathbf{2 0 0 7}$ & $\mathbf{2 0 0 8}$ & $\mathbf{2 0 0 9}$ & $\mathbf{2 0 1 0}$ & $\mathbf{2 0 1 1}$ \\
\hline Utang & 1,4 & 8,38 & 53,5 & 20,5 & 46,0 & 67,5 & 86,5 & 108,3 & 125,3 \\
Non Utang & 2,6 & 1,8 & 30,0 & 19,5 & 12,3 & 16,6 & 43,3 & 25,4 & 26,7 \\
\% pembiayaan defisit dgn utang & 35,0 & 82,3 & 64,1 & 51,3 & 75,8 & 80,3 & 76,7 & 81 & 83,1 \\
\hline
\end{tabular}

Sumber: Nota Keuangan, Buku Strategi Pengelolaan Utang, dan Beberapa sumber lainnya

Fenomena pergeseran struktur dan peranan utang tersebut menyebabkan akumulasi stok utang meningkat dan makin beratnya cicilan pokok dan bunga utang yang dibebankan pada anggaran pemerintah baik dalam anggaran belanja maupun pembiayaan pemerintah. Dalam enam tahun terakhir stok utang pemerintah menunjukkan peningkatan yang cukup signifikan. Pada akhir tahun 2006 stok utang pemerintah sebesar Rp.1.302 triliun, dan tahun 2011 menjadi Rp.1.804 triliun.

Tabel 2 Perkembangan Stok Utang, Pembayaran Cicilan Pokok, Maupun Bunga Utang Pemerintah 2005-2011 (Triliun Rupiah)

\begin{tabular}{lrrrrrr}
\hline & $\mathbf{2 0 0 6}$ & $\mathbf{2 0 0 7}$ & $\mathbf{2 0 0 8}$ & $\mathbf{2 0 0 9}$ & $\mathbf{2 0 1 0}$ & $\mathbf{2 0 1 1}$ \\
\hline Stok Utang Pemerintah & 1,302 & 1,389 & 1,637 & 1,591 & 1,677 & 1,804 \\
1. Pinjaman & 559 & 586 & 730 & 611 & 612 & 613 \\
2. Surat Berharga Negara & 743.0 & 803.0 & 906.0 & 979.0 & 1.1 & 1.2 \\
Rasio stok utang thp PDB & 39.0 & 35.2 & 33.1 & 28.4 & 26.1 & 24.4 \\
Pembayaran Bunga Utang & 79.1 & 79.8 & 88.4 & 93.8 & 88.4 & 106.6 \\
1. Dalam Negeri & 54.9 & 54.1 & 59.9 & 63.8 & 61.5 & 76.6 \\
2. Luar Negeri & 24.2 & 25.7 & 28.5 & 30 & 26.9 & 30 \\
Rasio Bunga Utang thp PDB & 2.4 & 2.0 & 1.8 & 1.7 & 1.4 & 1.4 \\
Pembayaran Cicilan Pokok Utang Luar Negeri & 52.8 & 57.9 & 61.3 & 69 & 54.1 & 47.2 \\
Rasio cicilan pokok thp PDB & 1.6 & 1.5 & 1.2 & 1.2 & 0.8 & 0.6 \\
Bunga + Pokok Utang & 131.9 & 137.7 & 149.7 & 162.8 & 142.5 & 153.8 \\
Rasio bunga dan pokok thp PDB & 4.0 & 3.5 & 3.0 & 2.9 & 2.2 & 2.1 \\
\hline
\end{tabular}

Sumber: Nota Keuangan 2012

Terkait dengan hal di atas, Lembaga Kajian dan Riset Ekonomi Bright Indonesia menilai bahwa kondisi utang pemerintah telah mengkhawatirkan, terutama berkaitan dengan beban pembayaran utang setiap tahunnya. Berdasarkan profil utang sebagaimana terlihat dalam tabel di atas, 
secara nominal beban tersebut cenderung tidak akan menurun pada waktu yang akan datang. Hal ini disebabkan stok utang terus meningkat, bahkan per akhir April 2013, stok utang meningkat menjadi Rp. 2.023,72 triliun. Jika ada guncangan eksternal atau melemahnya perekonomian domestik secara signifikan, maka beban utang pemerintah akan langsung memperparah keadaan.

Stok utang yang meningkat setiap tahun telah menyebabkan alokasi belanja pemerintah untuk membayar pokok dan bunga utang meningkat dua kali lebih besar dari alokasi untuk belanja belanja.

Tabel 3 Perkembangan Belanja Modal 2006-2011(Triliun Rupiah)

\begin{tabular}{lcccccc}
\hline & $\mathbf{2 0 0 6}$ & $\mathbf{2 0 0 7}$ & $\mathbf{2 0 0 8}$ & $\mathbf{2 0 0 9}$ & $\mathbf{2 0 1 0}$ & $\mathbf{2 0 1 1}$ \\
\hline Belanja Modal & 55,0 & 64,3 & 72,8 & 75,9 & 80,3 & 141,0 \\
Rasio thd PDB & 1,6 & 1,7 & 1,5 & 1,4 & 1,3 & 2,0 \\
\hline Bunga + Pokok Utang & 131.9 & 137.7 & 149.7 & 162.8 & 142.5 & 153.8 \\
Rasio thp PDB & 4.0 & 3.5 & 3.0 & 2.9 & 2.2 & 2.1 \\
\hline
\end{tabular}

Sumber: Kementerian Keuangan dalam Nota Keuangan 2012

Gambaran ini makin memperkuat anggapan bahwa pembiayaan fiskal dengan utang telah menyebabkan anggaran fiskal pemerintah makin terbebani,apalagi sepanjang krisis ekonomi dari 1997 hingga 2003 rasio utang pemerintah jauh di atas ambang batas yang ditentukan pemerintah sebesar 60 persen dari PDB. Menurut Arif dan Sasono (1987) dan Rachbini (2006), utang pemerintah yang telah melampaui batas, secara politik dapat berdampak buruk terhadap perekonomian domestik, bahkan Wibowo (2003) menyatakan bahwa utang pemerintah yang terlampau tinggi menjadi sumber ancaman bagi stabilitas ekonomi makro, baik melalui tekanan defisit fiskal, maupun cadangan devisa.

Sejalan dengan itu, Yuswar dan Mulyadi (2005) menyatakan, utang memang diperlukan pada tingkat yang wajar dan penambahan utang akan memberikan dampak positif terhadap pertumbuhan ekonomi,tetapi stok utang yang telah melebihi limit tertentu, akan membawa dampak negatif terhadap pertumbuhan ekonomi, bahkan dapat pula mengancam ketahanan fiskal (fiscal sustainability).

Berdasarkan fenomena di atas, penelitian ini bertujuan untuk menganalisis apakah pembiayaan fiskal pemerintah dengan utang yang dijalankan selama ini masih mempertahankan keberlanjutan fiskal (fiscal sustainability) atau tidak.

\section{Kajian Teori}

Pengertian fiscal sustainability dapat dipahami melalui accounting approach dan present value constraint approach (Rahayu, 2010). Kedua pendekatan ini didasarkan pada model government fiscal financing constraint (Cuddington, 1996). Model ini menyatakan bahwa:

$$
B_{t}=\left(1+r_{t}\right) B_{t-n}-S U R P B
$$

di mana:

Bt = jumlahutang (bonds) pemerintah yang beredar (outstanding) pada tahun $\mathrm{t}$;

rt $\quad=$ tingkat bunga;

SURPB = surplus pada primary balance.

Persamaan di atas menyatakan bahwa jumlah outstanding utang pemerintah sama dengan selisih antara bunga dan cicilan utang pemerintah dengan surplus primer (primary balance). Surplus primer itu sendiri adalah selisih antara anggaran penerimaan dan anggaran pengeluaran pemerintah di luar bunga dan cicilan utang. Berdasarkan persamaaan (1) di atas dapat diuraikan lagi menjadi: 
Atau

$$
B_{t}-B_{t-n}=r_{t} B_{t-n}-S U R P B
$$

$$
\Delta \mathrm{B}=\mathrm{r}_{\mathrm{t}} \mathrm{B}_{\mathrm{t}-\mathrm{n}}-\mathrm{SURPB}
$$

di mana $\Delta \mathrm{B}$ adalah tambahan utang pemerintah.

Dari persamaan dapat disimpulkan bahwa: (1) Apabila SURPB $=0$, maka utang akan bertambah sebesar bunga atas utang sebelumnya. (2) Apabila SURPB lebih rendah dari $r_{t} B_{t-n}$, maka $B$ positif, yang berarti pokok utang pemerintah terus meningkat. (3) Apabila SURPB lebih besar dari $r_{t}$ $\mathrm{B}_{\mathrm{t}-\mathrm{n}}$, maka $\mathrm{B}$ negatif yang berarti pokok utang pemerintah terus menurun. persamaan:

Bila persamaan (2) di atas dinyatakan dalam bentuk rasio terhadap GDP, akan diperoleh

$$
\frac{B_{t}}{Y_{t}}=\frac{(1+r) B_{t-n}}{(1+g) Y_{t-n}}-\frac{\operatorname{SURP}_{T}}{Y_{t}}
$$

di mana:

$$
\begin{array}{ll}
\mathrm{Yt} & =\mathrm{GDP} \text { tahun } \mathrm{t} \\
\mathrm{g} & =\text { real growth rate dari GDP }
\end{array}
$$

Persamaan (3) dapat disederhanakan menjadi:

$$
b_{t}=\frac{(1+r)}{(1+g)} b_{t-n}-s u r p b_{t}
$$

di mana:

$$
\begin{aligned}
\mathrm{b}_{\mathrm{t}} & =\frac{B_{t}}{Y_{t}} \text { yaitu debt/GDP ratio } \\
\text { Surpb }_{\mathrm{t}} & =\text { SURPB }_{\mathrm{t}} / \text { GDP ratio }
\end{aligned}
$$

Dari persamaan (4) dapat diperoleh perubahan rasio debt terhadap GDP sebagai berikut :

$$
\Delta b_{t}=b_{t}-b_{t-n}=\frac{r_{t}-g_{t}}{1+g_{t}} b_{t-n}-\operatorname{surpb}_{t}
$$

Menurut definisi accounting approach, defisit atau suplus pada primary balance adalah sustainable jika primary balance menghasilkan debt/GDP ratio yang konstan. Ini berarti $\Delta b_{t}$ dalam persamaan (5) harus sama dengan 0, sehingga:

$$
\frac{r_{t}-g_{t}}{1+g_{t}} b_{t-n}=s u r p b_{t}
$$

Pendekatan lain yang dapat digunakan adalah present value constraint approach (PVC). Dalam pendekatan ini sustainable dapat dipertahankan dalam kondisi No Ponzi Game (Greiner, A., Koeller, U. dan Semmler, W. (2006 )). Kondisi No Ponzi Game (NPG) dapat dipertahankan dengan melakukan iterasi ke depan terhadap persamaan (4) akan diperoleh :

$$
B_{t-1}=\sum_{j=0}^{N} \frac{\operatorname{SURP}_{t+j}}{(1+r)^{j+1}}+\frac{B_{N+1}}{(1+r)^{N+1}}
$$


Bila bagian terakhir dari persamaan di atas diambil limitnya menuju tak terhingga dan sama dengan nol, maka:

$$
\lim N \rightarrow \infty \frac{B_{N+1}}{(1+r)^{N+1}}=0
$$

Persamaan di atas memenuhi No Ponzi Game (NPG).

Kondisi NPG di atas menyatakan bahwa present value dari utang pemerintah di masa depan secara tak berhingga menuju nol (converges to zero). Hal ini dapat terjadi jika pertumbuhan utang secara riil lebih lambat dari pada tingkat bunga riil.

Penerapan kondisi NPG terhadap persamaan di atas menghasilkan:

$$
B_{t-1}=\sum_{j=0}^{N} \frac{\operatorname{SURPB}_{t+j}}{(1+r)^{j+1}}
$$

Persamaan ini disebut intertemporal government financing contraint. Persamaan ini menyatakan bahwa jumlah utang pemerintah pada saat tertentu harus sama dengan Present Value dari surplus primary balance di masa mendatang. Jika kondisi ini terpenuhi maka fiscal policy dianggap sustainable.

Chouraqui, Hagemann dan Sartor (1999) menyatakan bahwa ada tiga syarat yang harus dipenuhi dalam menilai kesinambungan fiskal pemerintah yaitu implementasi, interpretasi dan adanya kesamaan persepsi. Hal ini dimaksudkan untuk menghindari perbedaan-perbedaan pengukuran dalam hubungan antarnegara. Mereka menekankan pentingnya konsistensi kebijakan fiskal. Penerapan kebijakan yang berubah-ubah akan menyulitkan pengukuran kinerja. Dalam observasinya terhadap sejarah fiskal negara-negara OECD, menemukan bahwa Cyclically-Adjusted Budget Balance (CAB) merupakan cara efektif untuk saling mengontrol secara kolektif kestabilan fiskal masing-masing negara anggota. Hal ini bisa terjadi karena kebanyakan negara-negara Eropa Barat pasca Perang Dunia II berangkat dari kondisi perekonomian yang sama.

Buiter (1997) mengidentifikasi beberapa faktor yang memengaruhi kesinambungan fiskal. Fungsi identitas yang dielaborasi mencantumkan banyak variabel yang terkaitdengan penentuan stabilitas fiskal adalah:

$$
\begin{aligned}
& C_{t}+T_{t}+E_{t} N_{t}^{*}-F_{t}+A_{t}-P R I V_{t}+i_{t} B_{t-1}^{d}+i_{t}^{*} E_{t}\left(B_{t-1}^{*}-R_{t-1}^{*}\right) \equiv B_{t}^{d}-B_{t-1}^{d}+ \\
& E_{t}\left(B_{t}^{*}-B_{t-1}^{*}\right)+H_{t}-T_{t-1}-E_{t}\left(R_{t}^{*}-R_{t-1}^{*}\right)
\end{aligned}
$$

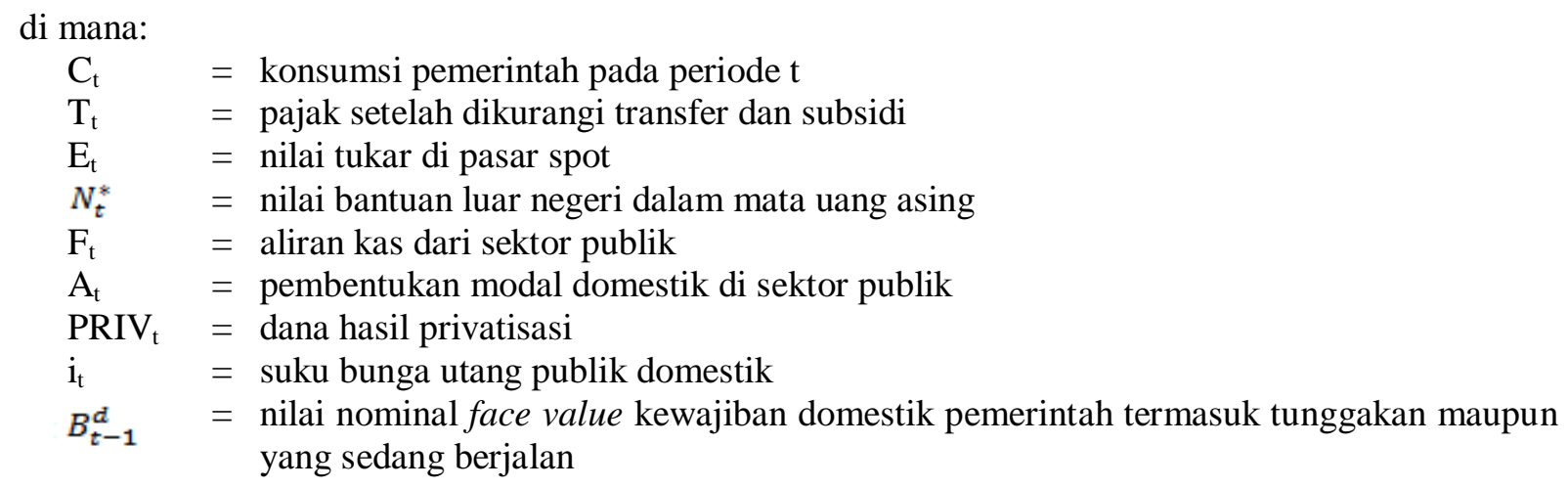


$i_{t}^{*} \quad=$ suku bunga utang dalam denominasi mata uang asing

$B_{t-1}^{*} \quad=$ nilai nominal kewajiban luar negeri termasuk bunga, tunggakan dankewajiban bank

$B_{t-1}^{*} \quad$ sentral dalam denominasi mata uang asing

$R_{t-1}^{*} \quad=$ cadangan devisa

$\boldsymbol{T}_{\mathbf{t}-1}=$ stok uang beredar

Dalam hal ketahanan utang, ada dua pendapat mengenai wacana indikator, yaitu yang berpegang pada surplus primer dan yang berpegang pada rasio utang terhadap PDB. Beberapa penulis seperti Cohen (2000) dan Marks (2003) menggunakan parameter rasio utang terhadap PDB sebagai indikator ketahanan fiskal. Pertumbuhan utang luar negeri tidak boleh lebih cepat daripada pertumbuhan ekonomi.

Buiter (1995) menawarkan tiga pilihan proxy yang berbeda dalam mengukur kesinambungan fiskal, yaitu rasio utang publik terhadap PDB, one-period primary gap dan permanent primary gap. Buiter menyebut penurunan rasio utang terhadap PDB sebagai indikasi kemampuan menjaga solvabilitas jangka panjang. Selain itu Buiter jugamengidentifikasi variabel-variabel yang dapat memengaruhi solvability fiskal, yaitu: (1) Rasio utang terhadap PDB. (2) Rasio surplus primer terhadap PDB. (3) Suku bunga jangka panjang. (4) Pertumbuhan ekonomi jangka panjang.

Primary Gap adalah selisih antara surplus primer aktual dan surplus primer yang diharapkan. Jika primary gap dihitung pada satu periode saja ( $\mathrm{t}$ ), maka hal ini disebut sebagai one-period primary gap. Namun, jika mempertimbangkan faktor solvability-nya sampai akhir periode utang maka primary gap tersebut disebut sebagai permanent primary gap.

One-period primary gap dapat dirumuskan sebagai berikut.

$$
G A P^{N}(0) \equiv\left(\frac{r_{t}-g_{t}}{1+g_{t}}\right) b_{t-1}-\sigma_{t}-s_{t}
$$

Sedangkan permanent primary gap dapat dirumuskan sebagai solvency gap berikut.

$$
G A P^{\infty} \equiv\left(\frac{r^{\infty}-g^{\infty}}{1+g^{\infty}}\right) b_{t-1}-\sigma_{A}^{\infty}-s_{A}^{\infty}
$$

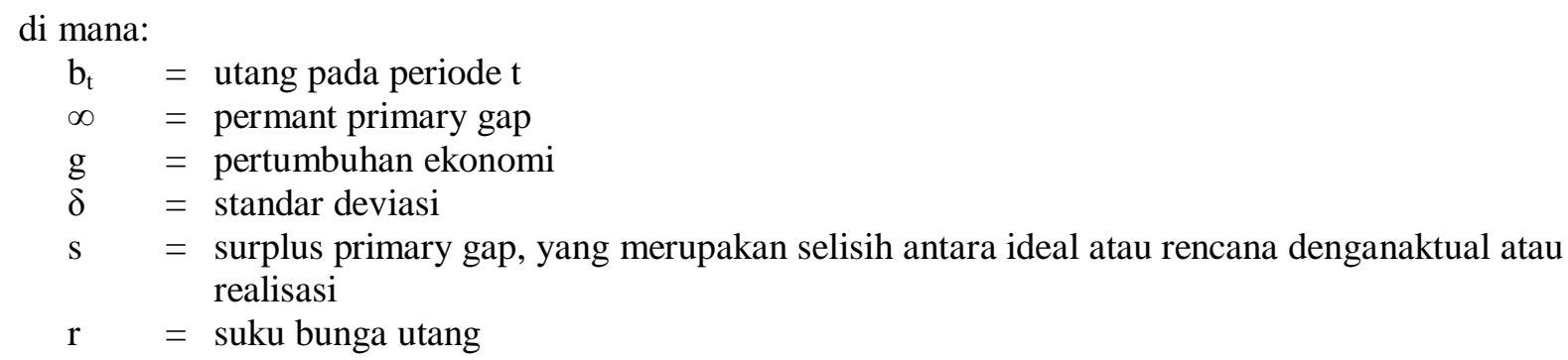

Berkaitan dengan keseimbangan primer sebagai indikator ketahanan utang, Bohn, H. (1998) mengamati respon surplus anggaran primer terhadap perubahan rasio utang terhadappendapatan. Respon yang positif menunjukkan bahwa pemerintah mengambil tindakan mengurangi pengeluaran non bunga atau meningkatkan penerimaan akan menghambat perubahan utang. Hubungan sistematis antara rasio utang terhadap pendapatan dan surplus primer ditunjukkan dengan persamaan regresi sebagai berikut. 


$$
s t=\rho^{*} d t+\alpha^{*} Z t+\varepsilon t=\rho^{*} d t+\mu t
$$

di mana:

$$
\begin{aligned}
\mathrm{Zt} & =\text { faktor-faktor lain yang memengaruhi surplus primer } \\
\mathrm{ct} & =\text { error term } \\
\mu \mathrm{t} & =\alpha \cdot \mathrm{Zt}+\varepsilon \mathrm{t} .
\end{aligned}
$$

Dalam kaitannya dengan sektor publik, konsep solvabilitas didasarkan atas kemampuan untuk memenuhi intertemporal budget constraint.

Dinh (1999) memaparkan sebuah pendekatan sederhana yang didasarkan padasolvabilitas dan kesinambungan untuk mengukur kinerja fiskal. Indikator yang digunakanadalah Fiscal Solvency Adjustment (untuk mengukur seberapa besar tambahan fiskalyang diperlukan untuk mencapai tingkat solvabilitas sektor publik) dan Fiscal Sustainability Adjustment (untuk mengukur seberapa besar usaha fiskal yang diperlukan tanpamenambah relatif utang internal maupun eksternal terhadap output). Model Fiscal Solvency Adjustment yang digunakan adalah sebagai berikut.

$$
S^{*}=\frac{B_{0}}{Y_{0}}(r-g)
$$

di mana:

$$
\begin{array}{ll}
\mathrm{S}^{*} & =\text { proporsi output yang harus dicapai agar tercipta solvabilitas pada sektor publik } \\
\mathrm{B} 0 & =\text { utang awal pemerintah } \\
\mathrm{Y} 0 & =\text { output }(\mathrm{PDB}) \\
\mathrm{r} & =\text { suku bunga } \\
\mathrm{g} & =\text { pertumbuhan ekonomi }
\end{array}
$$

Sedangkan untuk mengukur penyesuaian kesinambungan fiskal digunakan model Fiscal Sustainability Adjustment. Formula model tersebut adalah sebagai berikut.

$$
S^{* *}=\beta(r-g)+(1-\mu)\left(\frac{x}{y}\right) \beta^{*}\left(r^{*}+\hat{e}+\hat{x}\right)-\frac{1}{v}(\hat{p}+g)
$$

di mana:

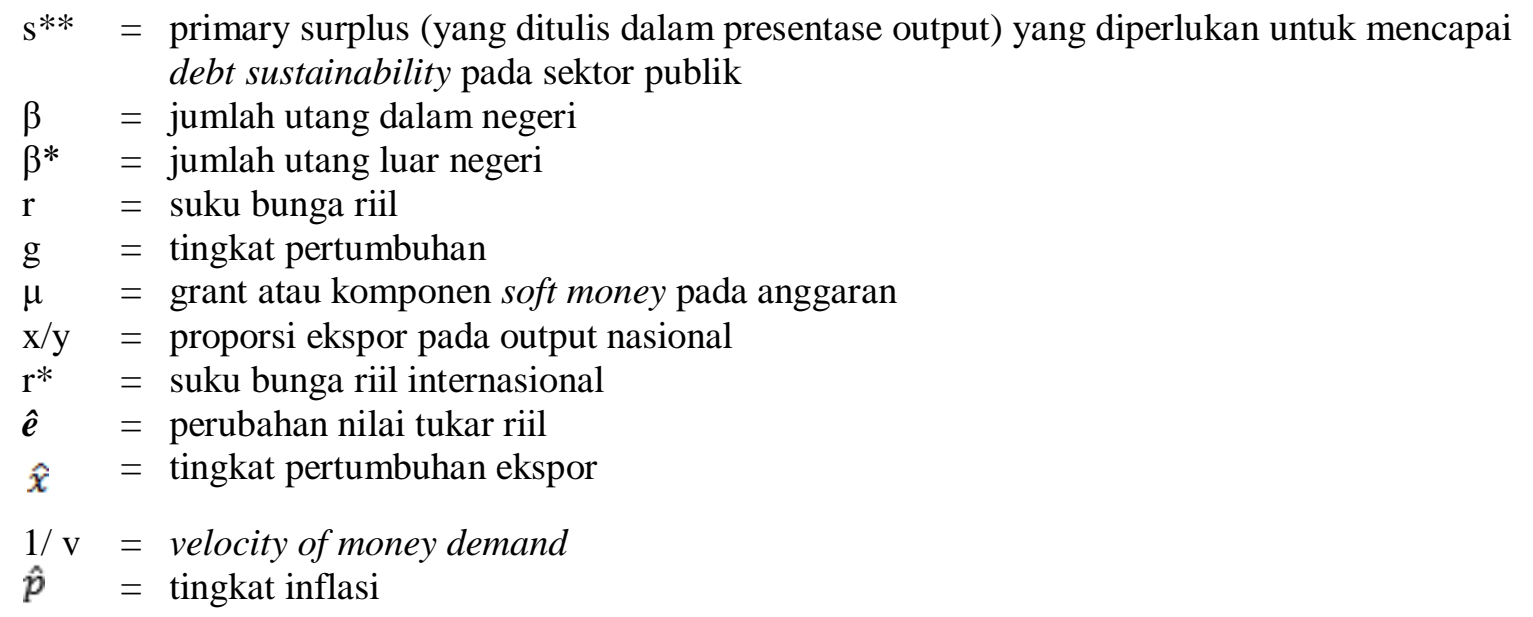

Menurut Roubini (2001), solvability akan tercapai bila pemerintah tidak meningkatkan jumlah utang lebih cepat dibandingkan tingkat bunga riil utang. Bahkan bila transaksi berjalan dalam keadaandefisit pun, solvability masih dapat dicapai jika terdapat potensi surplus di masa depan. 
Kriteria solvabilitas yang bersandar pada surplus tidak lagi realistis karena pemerintah seringkali tidak dapat berkomitmen penuh dalam mencapai surplus di kemudian hari. Selain itu, penyesuaian dalam mencapai surplus membutuhkan biaya yang sebagian besar berasal dari penerimaan pajak. Artinya, ada pergeseran orientasi pajak jangka panjang untuk orientasi surplus jangka pendek. Bila jalur kontraksi yang dipilih, maka pemotongan subsidi bagi masyarakat menjadi pilihan.

\section{METODE}

Mengacu pada kerangka teori yang dibangun di atas, dengan memodifikasi model Buiter (1997), model Cudington (1996) dan model Din (1999), maka model dampak pembiayaan defisit dengan utang terhadap ketahanan fiskal dapat dinyatakan sebagai berikut:

$$
\frac{d e b t}{G D P}=s_{t}+U L N P+U D N P+i r+i
$$

di mana:

$$
\begin{array}{ll}
\frac{d e b t}{G D P} & =\text { rasio utang terhadap GDP yang merupakan indikator ketahanan fiskal. } \\
\mathrm{S}_{\mathrm{t}} & =\text { surplus primer pada periode } \mathrm{t}(\text { selisih } \mathrm{G} \text { dan } \mathrm{T} \text { diluar cicilan pokok dan bunga utang). } \\
\mathrm{ULNP} & =\text { Utang Luar Negeri Pemerintah } \\
U D N P & =\text { Utang Dalam Negeri Pemerintah } \\
\text { ir } & =\text { suku bunga utang dalam denominasi mata uang asing } \\
i & =\text { suku bunga dalam negeri }
\end{array}
$$

Model di atas diturunkan dari asumsi bahwa utang pemerintah bersumber dari utang luar negeri dan utang dalam negeri. Secara matematis hal ini dapat ditulis sebagai berikut.

$$
\text { TLUP }=\text { ULNP }+ \text { UDNP }
$$

di mana:

TLUP $=$ total utang pemerintah

ULNP dan UDNP sudah didefinisikan sebelumnya.

Mengikuti model (1) sebelumnya, model dasar ketahanan fiskal dapat dituliskan kembali sebagai berikut:

$$
\text { TLUP }=\mathrm{f}(\text { ULNP, UDNP, SURPB })
$$

di mana:

SURPB = Primary balance (Kesimbangan primer) persamaan:

Persamaan ini dapat diubah kedalam bentuk relatif atau rasio terhadap PDB, sehinga diperoleh

$$
\frac{T L U P}{P D B}=\alpha_{0} \frac{S U R P B}{P D B}+\alpha_{1} \frac{U L N P}{P D B}+\alpha_{2} \frac{U D N P}{P D B}+\varepsilon
$$

Persamaan ini dapat disederhanakan menjadi: 


$$
\text { tlup }=\alpha_{0} \operatorname{surp} b+\alpha_{1} u \ln p+\alpha_{2} u d n p+\varepsilon
$$

di mana:

$$
\text { tlup }=\frac{T L U P}{P D B}, \operatorname{surp} b=\frac{S U R P B}{P D B}, u \ln p=\frac{U L N P}{P D B}, u d n p=\frac{U D N P}{P D B}
$$

Model 22 ini diasumsikan tingkat bunga dan laju pertumbuhan ekonomi adalah konstan. Oleh karena tingkat bunga merupakan faktor yang dapat memengaruhi keputusan untuk meminjam, maka dalam penelitian akan dimasukan sebagai variabel kontrol. Terkait dengan dua macam utang, suku bunga luar negeri (ir) dan suku bunga dalam negeri (SBI) akan dimasukan kedalam model, sehingga model 22 dapat ditulis kembali menjadi:

$$
\text { tlup }=\alpha_{0} \operatorname{surp} b+\alpha_{1} u l n p+\alpha_{2} u d n p+\alpha_{3} i r+\alpha_{4} i+\varepsilon
$$

di mana:

ir $\quad=$ Suku bunga luar negeri

$\mathrm{i} \quad=$ Suku bunga dalam negeri (SBI)

variabel lain telah didefinisikan sebelumnya.

\section{HASIL DAN PEMBAHASAN}

Berdasarkan fungsi tersebut, hasil estimasi model ketangguhan fiskal dapat dilihat pada tabel 4.1. Tabel tersebut memperlihatkan nilai koefisien surplus primer bertanda tanda negatif dan signifikan. Hasil ini menunjukkan bahwa jika suplus primer dapat dipelihara kenaikannya, rasio utang publik terhadap PDB dapat dikurangi. Ini berarti kesinambungan fiskal (fiscal sustainability) pemerintah makin terjaga. Hal ini relevan dengan yangdikemukakan oleh Cuddington (1996) dan Buiter (1995).

Fakta di atas menunjukkan bahwa jika surplus primer pemerintah dapat dipelihara kenaikannya misalnya sebesar 1 persen, rasio utang terhadap PDB dapat dikurangi rata-rata sebesar 3,2 persen. Hasil ini mendukung klaim pemerintah bahwa rasio utang pemerintah makin menurun seiring dengan meningkatnya surplus primer. Ini berarti pengelolaan anggaran pemerintah yang selalu menetapkan defisit anggaran dibawah tiga persen, menjamin kesinambungan fiskal pemerintah tetap terjaga. Argumen ini dikuatkan pula oleh hasil estimasi dimana pembiayaan defisit dengan utang baik yang bersumber dari utang luar negeri maupun utang dalam negeri tidak signifikan menyebabkan rasio utang pemerintah meningkat. Hal ini ditunjukkan oleh nilai koefisien RULNP dan RUDNP yang tidak signifikan. Temuan ini juga mengindikasikan bahwa kemampuan keuangan pemerintah untuk membayar utangnya tetap solvable.

Tabel 4 Hasil Estimasi Persamaan Rasio total Utang

\begin{tabular}{cccccccc}
\hline Variable & Coefficient & Std. Error & t-Statistic & Prob. & Adj. R-Square & Prob(F-statistic) & Durbin-Watson stat \\
\hline C & 0.766418 & 0.230475 & 3.325389 & 0.0027 & 0.649805 & 0.000043 & 1.353816 \\
SURPB & $-3.20 \mathrm{E}-02$ & $1.62 \mathrm{E}-06$ & -1.980844 & 0.0587 & & & \\
RULNP & 0.002132 & 0.002641 & 0.807338 & 0.4271 & & & \\
RUDNP & -0.004592 & 0.004592 & -1.000156 & 0.3268 & & & \\
IR & 0.089645 & 0.030096 & 2.978600 & 0.0064 & & & \\
I & 0.022322 & 0.004872 & 4.581646 & 0.0001 & & & \\
\hline
\end{tabular}

Sumber: Hasil Estimasi 
Syarat kedua dari ketangguhan fiskal ini dapat diuji melalui koefisien surpb sebesar -1 (satu). Melalui uji ANOVA dan uji Chi Square dapat dibuktikan apakah koefisien surpb memenuhi kaidah sama besar dengan -1 . Hasil uji tersebut diperlihatkan dalam tabel berikut.

Tabel 5 Wald Test

\begin{tabular}{lrrr} 
Equation: EQ_RTLUP & & & \\
\hline Test Statistic & Value & df & Probability \\
\hline F-statistic & 53.62804 & $(1,25)$ & 0.0000 \\
Chi-square & 53.62804 & 1 & 0.0000 \\
\hline Null Hypothesis Summary: & & & \\
Normalized Restriction (= 0) & & Value & Std. Err. \\
$1+\mathrm{C}(1)$ & & 1.766418 & 0.241211 \\
\hline
\end{tabular}

Sumber: Hasil Penelitian

Hasil uji di atas menunjukkan bahwa pada tingkat kepercayaan 99 persen, ketahanan fiskal didukung oleh data. Artinya kebijakan anggaran yang dijalankan pemerintah selama periode penelitian masih mempertahankan fiscal sustainability.

Walaupun demikian secara rata-rata rasio surplus primer kita masih sangat rapuh karena masih fluktuatif bahkan secara rata-rata masih negatif 0,11 persen (Gambar 1). Minimnya surplus primer mengindikasikan lemahnya ketersediaan dana yang dapat dimanfaatkan untuk membiayai pembangunan. Akibatnya kita masih akan tergantung pada utang meski dalam batas ambang aman. Oleh karena itu manajemen penggunaan utang harus dilakukan secara hati-hati, mengingat perubahan tingkat suku bunga baik suku bunga pinjaman luar negeri atau pun suku bunga SBI, kedua-duanya akan memengaruhi perubahan rasio utang terhadap PDB. Peningkatan tingkat suku bunga luar negeri akan mendorong peningkatan rasio utang terhadap PDB rata-rata 8,9 persen, sedangkan tingkat suku bunga SBI akan mendorong peningkatan rasio utang terhadap PDB rata-rata 2,2 persen.

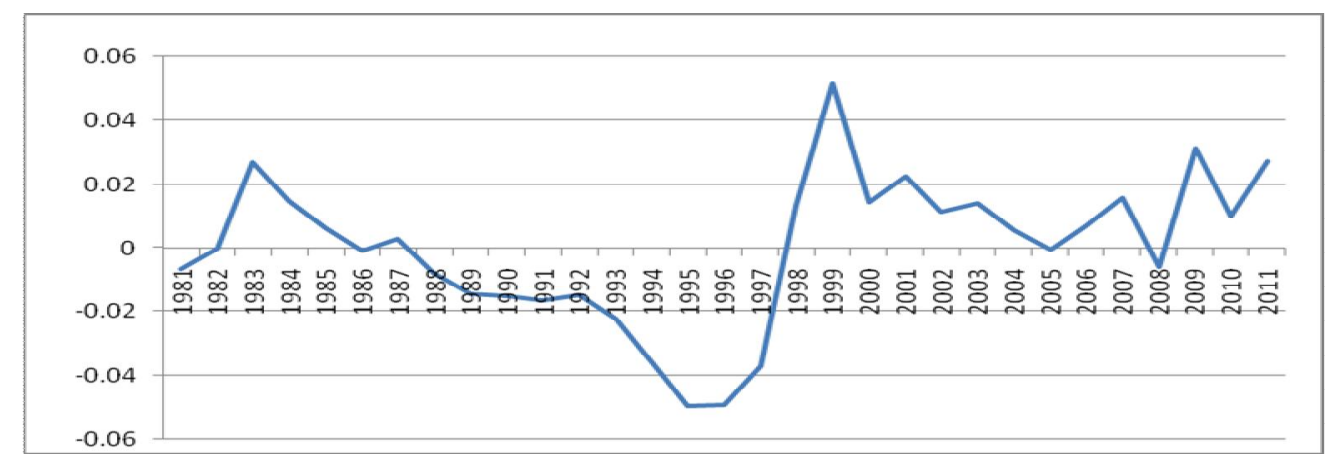

Gambar 1 Rasio Surplus Primer Terhadap PDB

Sumber: Hasil Penelitian, Data diolah

Secara teori hal ini memungkinkan karena peningkatkan suku bunga, secara otomatis akan mendongkrak naiknya utang pemerintah, baik utang luar negeri mapun utang dalam negeri. Keadaan ini pada akhirnya akan mendorong stok utangjuga akan makin meningkat. 


\section{SIMPULAN}

Berdasarkan hasil analisis dan pembahasan sebagaimana dikemukakan di atas, dapat disimpulkan bahwa pembiayaan defisit anggaran pemerintah dengan utang baik utang luar negeri maupun utang dalam negeri, masih mempertahankan fiscal sustaibility. Namun demikian pemerintah harus hati-hati dalam penggunaan utang karena kenaikan suku bunga pinjaman, baik suku bunga pinjaman luar negeri maupun suku bunga pinjaman dalam negeri akan menyebabkan rasio utang meningkat.

\section{DAFTAR PUSTAKA}

Arif, S., Sasono, A. (1987). Modal Asing, Beban Utang Luar Negeri dan Ekonomi Indonesia. Jakarta: UI Press.

Bohn, H. (1998). The behaviour of U.S public debt and deficits. Journal of Economics, 113(3), 949963.

Buiter, W. H. (1997). Aspects of Fiscal Performance in some Transition Economies under Fund. Supported Programs, IMF.

Chouraqui, J. C., Hagemann, R. P., Sartor, N. (1999). Indicators of Fiscal Policy: A Reexamination. OECD, Working Paper, 78.

Cohen, D. (2000). The HIPC Initiative: True and False Promises. OECD Development Center.

Cuddington, J. T. (1996). Analyzing the Sustainability of Fiscal Deficits in Developing Countries. Washington D.C., USA: University of George Washington.

Dinh, H. T. (1999). Fiscal Solvency and Sustainability in Economic Management. Working Paper World Bank.

Greiner, A., Koeller, U., Semmler, W. (2006). Testing the sustainability of German fiscal policy: evidence for the period 1960-2003. Empirica, 33.

Marks, S. V. (2003). Fiscal Sustainability and Fiscal Solvency: Theory and Recent Experience in Indonesia. Disiapkan untuk Bappenas, Pegasus Consulting.

Rachbini, D. J. (2006). Ekonomi Politik dan Teori Pilihan Publik. Edisi Kedua. Jakarta: Ghalia Indonesia.

Rahayu, A. S. (2010). Pengantar Kebijakan Fiskal. Jakarta: Bumi Aksara.

Roubini, N. (2001). Why Should the Foreign Creditors of Argentina Take a Greater Hit/Hair Cut Than the Domestic Ones. Working Paper Series, NBER.

Wibowo, D. (2003). Optimalisasi Manajemen Utang Luar Negeri Pemerintah. Diakses dari http://www.kau.or.id/articles.php?lng=en\&pg=192,

Yuswar, Z. B., Mulyadi, S. (2005). Keuangan Negara dan Analisis Kebijakan Utang Luar Negeri. Jakarta: Penerbit Raja Grafindo Persada. 